\title{
FARM FAMILIES AND FUTURE OPTIONS - THE ROLE OF THE EXTENSION ADVISORY SERVICE IN SHAPING IRISH AGRICULTURE
}

\author{
John McDonagh, Maura Farrell, Marie Mahon \\ Department of Geography, School of Geography and Archaeology, National University of Ireland, Galway
}

Manuscript received: February 2013

Revised version: September 2013

\begin{abstract}
McDonagh J., FarRell M., Mahon M., 2013. Farm families and future options - the role of the extension advisory service in shaping Irish agriculture. Quaestiones Geographicae 32(4), Bogucki Wydawnictwo Naukowe, Poznań, pp. 49-62, 1 fig. DOI 10.2478/quageo-2013-0033, ISSN0137-477X.
\end{abstract}

ABSTRACT. Agriculture across Europe is very much driven by the reforms initiated by the European Union (EU) and World Trade Organisation negotiations. Reforms have mobilised a shift in agricultural practices from production to a somewhat contested post-production and, more recently, multifunctional agriculture regime. Accompanying such change has been the debate on the future of farming, the role of agriculture within the countryside, and the extent to which the sector will maintain support from the Common Agricultural Policy (CAP) and the EU. Central to these discussions, in terms of bringing about beneficial change on farms and in rural areas, is the advice and direction available to farmers. The agricultural extension advisory services are an integral component of this process. This paper explores the position of public extension advisory services in Ireland and determines the extent to which these services are impacting the trajectory of modern agricultural practices within a framework of more traditional views of farmers and farm families.

KEY WoRDs: agriculture, rural, extension advisory services, sustainability, Ireland

John McDonagh, Department of Geography, School of Geography and Archaeology, National University of Ireland, Galway, Ireland; e-mail: john.mcdonagh@nuigalway.ie

\section{Introduction}

The European Union (EU) is increasingly moving away from the productivist dominance of the 1970s, 1980s and early 1990s to more multifunctional practices which "reconfigure rural resources in ways that lead to wider development benefits" (Marsden, Sonnino 2008: 422) and where the persistence of family farms (Moreno-Pérez et al. 2011) remains a key concern. Shortall (2004: 35) describes this remodelling as a "fundamental shift from ideologically supporting sectoral policies (agriculture) to supporting more spatial (rural) policies". McDonagh (2013) suggests that not only does such a reorientation towards rural development reposition agriculture's place in rural society but the "proposed readjustment sees the farming body engage in a range of diversification processes related to their viability while also meeting wider objectives, such as quality food, environmental services and landscape protection" (2013: 5). Allied to this changing landscape is the uncertainty brought about by the current economic crisis and continuing global challenges of food security, energy security and climate change. Thus, in a radically re-shaped country- 
side, concerns for economic, social and particularly environmental sustainability have never been greater. As a consequence, the concept of the multifunctional countryside gains greater acceptance with the rural becoming "a place of consumption and production, where new interests and uses of rural areas emerge and where local and global economies become more incorporated" (McDonagh 2013: 5). A central component of this remodelling of rural areas, farm enterprise and pursuit of new innovations, sees the agricultural sector "immersed in a long-term process of reorganization so as to accommodate (change)" (Lopez-i-Gelats et al. 2011: 783). Indeed, such reorganisation is considered an essential "strategy for farmers as a response to reduced profitability and change in traditional farming" (McNally 2001, cited in Grande 2011: 220) and is inherently beneficial both to rural areas and farmers' future viability. This is played out through new pathways being pursued, such as off-farm employment, developing on-farm enterprises, providing environmental or recreational services (Alsos, Carter 2006; Barbieri, Valdivia 2010), and wider rural development initiatives (Grande 2011) which ultimately impact local rural economies and societies. Ultimately, with the pace and intensity of contemporary change the "type, extent and applicability of advice and information that farmers receive is crucial to their future sustainability" (Farrell et al. 2008: 40). In the remainder of this paper, the organisation charged with overseeing the advice given to Irish farmers will be explored; the traditional ways in which such advice has been given, critiqued, and the recognition of current shortcomings and suggested ways forward, identified. Before delving into the sphere of extension advisory services, it is useful initially to provide a contextual setting in which the extension services operate.

\section{Irish agriculture - from production to multifunctionality}

Rural Ireland has undergone deep-seated change, challenge and opportunity in the last three to four decades. Conditioned by processes of globalisation and international policy developments, the rural economy of Ireland is challenged like all others to respond to growing demands for more competitive, innovative and knowledge-based economies, underpinned by the ideal of a 'living countryside' and an acceptable quality of life within rural locales. In historical terms, Ireland has an interesting rural past. Marked by divergent paths, this past has seen a shift in the importance of small farms and attempts at self-sufficiency (in the 1940s), to one which embraces a more open, outward and sophisticated economy and gateway to Europe, to the challenge of a global economic crisis and the re-emergence of agriculture as a key driver in economic recovery. In fact, it has been argued, with greater vigour now than for many decades, that "farmers are a critical component of (the) rural environment and it is the renewal and development of core farming activities, in a balanced and sustainable manner, which are vitally important for future sustainability" (Lenihan et al. 2002: 94).

One of the seminal moments in Ireland's rural past was its accession to the EEC (now EU) in 1973. While it is difficult to predict what path Ireland may have followed had it not joined the $\mathrm{EU}$, there is no doubting that in doing so, its development has been very much impacted by the policies and direction of Europe ever since. In a very fundamental way, Ireland's membership of the EU reinforced the inherent policy of productivism which had been embedded in Irish agriculture for many decades (Share et al. 2007). This productivist ideology led to the gradual but definite decline in the proportion of rural people who were farmers, with the proportion of the Irish labour force engaged in agriculture falling to 1 in 12 (approx.) by the mid-1990s (Commins 1995). The introduction of post-productivist policies further exacerbated this decline with the number of farmers in the Republic of Ireland falling to under 7\% in 2004 (CSO 2004). The continued difficulty of an ageing farm body (Share et al. 2007), with family farm members seeking employment in perceived secure labour markets elsewhere, were additional contributory factors to this decline. The introduction of the MacSharry Reforms (1994) and consequent policies (the Rural Protection Scheme (REPS) in 1994, for example) which sought to address the excesses and damage to the environment that typified the productivist era, further de-skilled the countryside. These policies, 
while being very popular (over 400,000 farmers signed up by 1999, accounting for just under one-quarter of all farms and almost one-third of the total area farmed), placed added demands on farmers in terms of their role as stewards of the countryside as opposed to their more instinctive skills of being the primary producers of the nation's food and fibre. This shift further required a reappraisal what farming entailed and issued in a "renewed interest in moving away from 'industrialized agriculture' (with) additional focus on local, organic, artisanal and non-food producing functions and 'public good' conceptualization of the rural" (McDonagh 2013: 3).

The McSharry reforms were also answerable for a further and very noteworthy change in Irish agricultural practices, namely the increased dependence on direct payments. By the second half of the 1990s, Irish agriculture had switched in emphasis from market support systems towards direct payments, resulting in payments to Irish farmers reaching over $£ 1,000$ million by the end of 1997 (Teagasc 1998). The impact of this change in Irish agriculture was to increase substantially the dependence of farmers, with the exception of dairy farmers, on the 'cheque in the post' for a farm income (Frawley, Keeney 1999). An issue of concern here was the fact that the vast amount of direct payments were received by the top $30 \%$ of the farmers, creating an economic gap within the farming community. The smaller, less intensive farmers were increasingly pressurised to maintain their farm income in the face of quotas and limited opportunities for expansion. Between 1971 and 1996 the total farm labour force declined by $54 \%$ and individuals who recorded their principal occupation as that of 'farmer' dropped from 210,000 in the 1961 census to 100,000 in 1996 (Lafferty et al. 1999: 11). By 2004, the Irish Department of Agriculture and Food had begun to implement the preliminary stages of the changeover programme for decoupling, which was part of the Mid-Term Review (MTR). By the time the Mid-Term Review was introduced, the number of farms in Ireland had declined by $17 \%$ and the number recorded as full-time farmers fell by $24 \%$. Although population figures in rural areas had experienced unprecedented growth, and national labour force figures within the same period grew by $57 \%$, the percentage of people employed in agriculture fell from 14\% to 5\% (Crowley 2003: 3). While Lucey (2004) suggested that the decisions taken by many farmers to produce would be heavily influenced by market signals and unless market returns were acceptable there would be little or no incentive for farmers to maintain production levels, a case study carried out by Breen et al. (2005), assessing the impact of decoupling on farming in Ireland, revealed that even though there were significant changes in profitability arising from decoupling, the majority of farmers surveyed fully intended to continue as before and were unlikely to change their production patterns. What did result, however, was a decline in family farm income (FFI) from $€ 14,236$ in 1995 to $€ 11,998$ in 2002 (Connolly et al. 2003) and increases in part-time farming and off-farm employment demands. Effectively, a far different rural landscape in terms of use and opportunity was rapidly emerging.

These fundamental changes, with their increased acceptance of practices such as part-time farming, off-farm employment, farm diversification and engagement in environmental regimes, essentially capture what we understand as the multifunctional countryside. The emergence of this multifunctional countryside projects an 'alternative end-point' that acknowledges that productivist and post-productivist action can occur simultaneously, spatially as well as temporally (Potter, Burney 2002; Wilson 2001; Wilson, Rigg 2003). Potter and Burney (2002: 35) suggest that such multifunctionality can be seen as a method of "producing not only food but also sustaining rural landscapes, protecting biodiversity, generating employment and contributing to the viability of rural areas". The 2005 National Farm Survey (NFS) stated that on $55 \%$ of all farms the farmer and/ or spouse had an off-farm job; on $38 \%$ of farms a job was held by the farmer, and overall, on $81 \%$ of farms the farmer and/or spouse had some source of off-farm income, be it employment, pension or social assistance (Connolly et al. 2005: 2). An examination of these figures shows that in order to sustain the farm household income, the spouse or the farmer or both had to engage in off-farm employment. Subsequently, many farm families increasingly question the sustainability and viability of their farm and seek out alternative direction regarding enterprises on farm 
or part-time employment off-farm. As a result, the wider rural environment becomes increasingly important to the farming community and this has been gradually reflected in the changing policy with its reorientation toward a broader rural development agenda. It is also worth noting, however, that the farming community can hold multiple attitudes (to change) which in turn lead to the practices of a variety of behavioural choices. Therefore, although the farming community may choose to engage in farm diversification and environmental farm practices, the 'mindset' of the farming community may still be firmly entrenched in productivism (Burton, Wilson 2006), a situation which is particularly challenging for extension services. That is, extension professionals may become engaged in administering advice and information in relation to pluri-activity, but effect no significant 'shift in thinking' or change in 'mindset', and thus remain firmly fixed in delivering technical advice that only holds relevance to commercially viable farmers (Farrell 2009). To this end, ability and/or willingness of extension advisory services to adapt and provide advice that is relevant to a wider rural community and not just a farming one, proves the main yardstick in determining their relevance in impacting future rural sustainability.

\section{Agricultural extension advisory services - past and present}

Extension services have a long history, dating from the middle of the $19^{\text {th }}$ century and the potato famine (1845) in Ireland. Responding to perceived needs in farming practices and/or alternative cultivation, the British government arranged for 'practical instructors' to travel rural areas to engage with small farmers about their future practices (Farrell 2009). This development gained attention across Europe in Germany, Denmark, the Netherlands, Italy and France, leading to the establishment of extension services with in excess of one million employees (Jones, Garforth 1997). In its earliest conception, extension services were small-scale and limited. Essentially, agricultural extension services were charged with the supply of agricultural information to the farming community, in the "conscious use of communications of information to help people form sound opinions and make good decisions" (van den Ban, Hawkins 1996: 9). Advisers within this system were limited in scope, with their remit focused on the dissemination of production and technical advice.

Rapid transformations in agriculture and the restructuring of rural economies did, however, force extension services to question their contribution to the farming body and encourage, however slowly, a progression in their role in shaping farming practice. In more recent times, there have been concerns raised on the focus of extension services and their continued concentration on the transfer of agricultural technology in a very top-down paternalistic approach, rather than one that values the contribution and problem-solving capacity of the farming community (Farrell 2009; Qamar 2001). In a contemporary sense, we see society's expectations of the rural manifest themselves in a myriad ways. Driven by concerns with food security, energy security and climate change demands, the activities in rural space, and particularly the activities of farmers and agriculture, are being viewed in far more complex and interconnected ways. The traditional conception of agriculture equating to rural and vice versa has been consigned to historical treatise, with the multifunctional countryside being thought of as the norm rather than the exception. To this end, the place of the extension advisory services has to be rethought in terms of their ability to engage with this broader remit and the necessity to step outside of their 'comfort zone' in addressing the broader changes facing rural areas as opposed to those facing farmers. Essentially, the farm family is considered a group that has a number of educational needs, of which agriculture is just one (Qamar 2001). Consequently, we have seen more recently the introduction of a broader range of services relating to marketing, environmental conservation, poverty reduction, rural development issues, and off-farm activities (World Bank 2002). In this way extension services are seen as a series of embedded communicative interventions that are meant, among others, to develop and/or induce innovations which supposedly help to resolve (usually multi-actor) problematic situations (Leeuwis, van den Ban 2004). This broader scope sees extension advisory services placing a greater 
emphasis on farmer-first and participatory approaches (Pretty, Chambers 1994). However, it is also important to note that the need to assimilate new information at a rapid pace may place advisers in the invidious position of possibly being unsure of their knowledge base, while all the time carrying the weight of expectation from farmers to deliver solutions for them (Farrell 2009). While this top-down method of extension has gradually been replaced by more participatory approaches, it still remains a fallback position for many advisers in developed countries, where there are still indications that extension advisory methods tend to retain this traditional and 'paternalistic' model of communication (Cristóvão et al. 1998).

This shift in thinking and process therefore has not been a straightforward or easy transition. Van den Ban and Hawkins (1996) recognised this in their highlighting of how extension advisory services are judged by their capacity to transfer knowledge from researcher to farmer, advising farmers in their decision making and educating them on how to make more informed decisions. While this could be viewed as human resource development (Swanson, Samy 2002), as farms and rural enterprises become increasingly diverse, the type of knowledge and information required exceeds the traditional routine of promoting specific farming practices or technologies. Consequently the traditional 'one size fits all' approach (Garforth 2004) is no longer a suitable method of dissemination. Indeed, in the 1980s, public-sector extension services were criticised for failing to remain relevant and valuable to the farming community; for insufficient impact; for not being effective; for not being efficient; and for not pursuing programmes that promoted equity (Rivera 1996; Rivera, Qamar 2003). Such public and political disapproval resulted in a reduction in public funding and increased competitive interests from private extension organisations (see Fig. 1 for some of the advantages and disadvantages of private extension organisations). Many governments, however, were reluctant to relinquish complete control of extension organisations as they were still believed to be essential for the medium to the small farmer unable to pay excessive fees for private extension services, as well as being a valuable policy instrument in helping to achieve their goals (van den Ban, Hawkins 1996).

The diverse farming practices that were becoming an acknowledged part of the Post-Productivist Agricultural Regime (PPAR) required new and innovative extension methods (Garforth et al. 2003). Farmers began to be recognised as full collaborators in research and extension (Black 2000; Haug 1999; Murray 2000; Pretty 1995), and subsequently more participatory, bottom-up methods of extension gradually began to emerge. Pretty and Chambers (2000: 190) describe this new paradigm for agricultural research, development and extension as reflecting farmer-first and participatory approaches, albeit they are cognisant of the increasing complexity, diversity and uncertainty of situations and contexts. Such paradigm shift implies not only new learning

\footnotetext{
Advantages:

- more targeted effectiveness - farmers can select an adviser who is best able to help their particular situation

- more efficient - when farmers are paying, they are more likely to prepare carefully and use the time better to get the best value for their fee

- farmers may be more inclined to follow advice which they have paid for themselves

- advisers are unlikely to have roles in the implementation of government polices

- advisers are likely to be more accountable for advice given

Disadvantages could include:

- hamper the free flow of information (public advisers often contribute to farm magazines, radio, TV and so disseminate "free" advice)

- farmers may be less inclined to share information with other farmers (having paid for the advice themselves)

- greater concentration on larger/commercial farmers who can afford the services

- tendency to concentrate on topics for which farmers are willing to pay a fee (rather than those that might have a greater public good)

- fully private availability of extension services would not be feasible in countries with large numbers of small-scale subsistence farmers

- unlikely to deal with social and/or environmentally optimal services
} 
approaches, but also new institutional arrangements within which participatory approaches can be facilitated. This particular approach recognises farmers as experimenters in their own sphere of influence and allows them to access information that permits them to make their own decisions (Pretty 1995; Somers 1998; Swanson, Samy 2002; Thrup, Altieri 1998). These new institutional settings include a "shift away from centralised decision-making, from static and fixed modes of planning for services, field learning by dialogue and participatory methods, iterative learning within the institution and inter-institutional linkages" (Pretty, Chambers 2000: 194). This participatory approach to extension seeks to include all actors in identifying associated problems and attempts to identify solutions to such problems. In doing so, a participatory approach recognises the value of a variety of perceptions, which, according to Murray (2000: 522), challenges the old paradigm in which a 'top-down' notion of extension recognises the opinion of an expert and in turn assumes that the farmer will adopt the solutions delivered.

There are difficulties, however, for advisers in making such a conceptual shift, and the impact this has had for moving towards a participatory approach has arguably been underestimated (Farrell 2000). These difficulties are reflected at the institutional level in certain characteristics and practices that remain in place within the institutional framework of public extension services (Rivera et al. 2001). Some of these include: dependence on the broader policy environment (particularly the lack of co-ordination between other agencies and the research arena); interaction with knowledge generation (weak influence in setting research priorities); difficulty in attributing impact (undermining incentives by advisers that are not measurable in terms of outcomes, and encouraging focus on input indicators); weak accountability (difficulty in measuring quality of outputs, no mechanisms for accountability to farmers); public duties other than knowledge transfer (supervisors and advisers are incentivised via quantifiable performance criteria, e.g. grant or loan applications, statistical reports) (Feder et al. 2001). Advisers can be caught between what Rivera (2008) describes as participatory models that promote greater collaboration with farmers on the one hand, and the capitalist, commercial reality of agriculture as business on the other (Murray 2000; World Bank 2002). Another, related issue is the extent to which advisers, as professionals, accept the ideology of participation as part of delivering extension advice (Farrell 2009).

In a rapidly changing multifunctional environment, the ability of advisers to adapt, to absorb new knowledge, to adjust their advice and its method of delivery, not only in line with their own changing situation, but in relation to the changing situation of farmers, is of crucial importance (Farrell 2009). In addition to new skills, advisers also require a considerable shift in 'mindset' and a much wider range of knowledge than required by earlier generations of agricultural advisers (Garforth et al. 2003). As "agents of change" (Carey 2004) advisory services have a dual responsibility of not only advising farm households, but also showing the ability to change internally. This implies fluidity and reflection in terms of goals and objectives that are not just reactive to the policy environment, but which also change proactively and attempt to influence the directions in which policies might be headed. The evidence of such a reflexive approach would suggest room for improvement in that many advisers tend to remain attached to traditional modes and procedures of advice delivery, and many are still rooted in a productivist agricultural ethos (Farrell et al. 2008; Rivera, Qamar 2003).

\section{Irish extension advisory services}

Irish extension advisory services are essentially dominated by the state-supported Teagasc organisation. Teagasc, the Agriculture and Food Development Authority established in September 1988 under the Agriculture Research, Training and Advice Act, 1988, has been charged with delivering research, advice, education and training to the farming community since its inception (Phelan 1995). The current mission statement of Teagasc is "to support science-based innovation in the agri-food sector and the broader bioeconomy that will underpin profitability, competitiveness and sustainability" (www.teagasc.ie). Teagasc is largely funded by the State (approx. 75\%) from client fees, fees for research, training services, project funding, and farming and commodity 
levies. Teagasc employs 1,200 staff and is a client-based organisation that operates in partnership with all sectors of the agricultural and food industry and with rural development agencies in the Republic of Ireland.

In terms of the evolution of extension advisory services in Ireland, we can see that there was an initial conventional top-down, one-way transfer of technology model (Pretty, Chambers 1994) whereby processes of increased specialisation on farms were deliberately encouraged (Leeuwis 1989) with a push for increased production through the adoption of new technologies and improved practices (Phelan 1998). This 'paternalistic' method of extension dominated and involved transmitting a technical agricultural message from 'sender' to 'receiver', i.e. from those in authority, government planners, advisers or researchers to a farmer who was often uneducated and ill-informed (Cristóvão et al. 1998). Indeed, this student-teacher-like relationship concentrated on providing information that advanced the productivist model of agriculture in addition to instilling an expectation amongst the farming community that advisory services will provide the answers to their changing situations. Allied to favourable policies, extension advisory services in Ireland were extremely successful in their objective to increase production and productivity, albeit there was little foresight in terms of how this increased production would impact wider rural society, economy and environment. Many traditional farming practices ceased, with smallscale family farms becoming increasingly marginalised in terms of viability unless assisted by an off-farm job or alternative on-farm enterprise.

The emergence of the PPAR brought about extensive change to both the structure of Teagasc extension services and the type of advisory programme delivered. Extensive efforts were made by the advisory services to curtail production levels and improve efficiency at farm level (Phelan 1998). The introduction of fees for advisory services alienated some farmers and to an extent favoured the more commercial farmers who had greater ability to pay. Nevertheless, with the onset of direct payments, subsidies and other EU payments, the increased necessity for 'form filling' meant small-scale farmers still needed the help of the advisory service, and to a degree, this propelled the advisory service increasingly into a 'paper enterprise' (Farrell 2009).

In response to EU policy directives and market changes, Teagasc restructured its extension advisory services in the mid-1990s. In an attempt to recognise the changes in agriculture and in rural areas, Teagasc established three different service departments: a commercial service, a farm viability service, and a rural enterprise service (Teagasc 1995). In theory, Teagasc were moving in the right direction, albeit Phelan (1998) argues that an increased focus on income generation, coupled with an augmented demand from the farming community to obtain direct payments, led to severe difficulties for extension professions that had already experienced a reduction in staffing numbers. In addition, the PPAR brought with it a reduced need for the technical production advice that Teagasc had perfected down through the years. A wider range of skills were now required to provide the farming community with the advice and information they required to ensure viability in the broader rural framework (Farrell 2009). Failing to become engaged in the broader rural framework and advising their clients accordingly would see Teagasc become an extension service that continued to provide valuable technical information for a strong commercial sector within Irish agriculture, but one which struggled to support non-commercial farmers that wanted to maintain or increase their income in a non-traditional manner. By the late 1990s, with Irish agriculture engaged in a multifunctional trajectory in which productivist and non-productivist agriculture co-existed, Teagasc were compelled to connect with wider rural development issues in order to maintain a solid client list and a viable advisory service.

In the next section, two contrasting examples highlight some of the issues faced by the extension advisory services in engaging with broader rural development, in maintaining relevance, and in responding to the demands of a multifunctional countryside. The evidence for this section is drawn from fieldwork conducted by the authors during the period 2007-2010. This fieldwork utilised a series of methods and databases including surveys, face-to-face interviews, discussions with key stakeholders, and data from the National Farm Survey. The National Farm Survey (NFS) is 
a member of FADN, the Farm Accountancy Data Network of Europe, and is designed to collect and analyse information on over 1,000 selected farms (representing over 115,000 farms) throughout the Republic of Ireland.

\subsection{Discussion groups (DGs)}

Discussion group fora have long been a part of the armoury of the extension advisory service. From their initial appearance in New Zealand in the 1950s and Australia in the 1960s, DGs have increasingly become ever-present in the advisory services of the UK and Ireland. In terms of the latter, DGs have become a dominant vehicle in imparting knowledge from advisor to farmer since the 1980s, their value reinforced by their central role in promoting the uptake of policy measures such as the Dairy Efficiency Programme (DEP) and the Beef Technology Adoption Programme (BTAP). Discussion groups are exactly as could be expected in that they involve farmers coming together to discuss different farming practices, new technologies, new ideas, and ways of implementing change. Watson (2012) describes one of his key roles as an extension advisor in facilitating discussion groups and allowing farmers the opportunity to learn from each other's experiences, alongside providing additional information (changes in criteria for grant-aid for example), organised farm walks, practical demonstrations and such like, while all the time providing a critical eye on the farmers business. Indeed, Morrison (2012: 13) suggested that one of the more valuable aspects of the advisors' role was the importance of farmers having "a source that is independent and not 'tainted' by commercial interests". Byrne (1997, cited in Hennessy, Heanue 2012: 45) outlined the five main advantages of discussion groups in terms of "sharing knowledge and experience of other farmers; group members benefit by seeing how other farmers sort out particular problems or how other farmers operate; they pick up ideas that may be used on their own farms; it helps keep them up to date with, and avail of, the advice of the farm advisor". Boyle (2012: 5) recognised the importance of the 'stakeholder-to-stakeholder' networks that are facilitated through the discussion groups and how "these networks have increased significantly in recent years through the DEP and BTAP measures". All in all, the concept of discussion groups is a very positive example of the way in which extension advisory services play a very important role in terms of farming practices. The response, as reported both through research study and via conference proceedings (Heanue $e t$ al. 2012), suggests a highly regarded relationship between advisor and farmer that is much valued by those involved.

There are, however, some issues about the value and reach of discussion groups. In particular it is important to note that there are issues around the target audience and the openness of farmers to new ideas. Specifically, there seems to be a strong correlation between membership of discussion groups and larger, more commercially oriented farmers. Hennessy and Heanue (2012) suggest that there can often be issues around group dynamics, with some groups working better than others. Boyle (2012: 5) also refers to the take-up by farmers, suggesting that while discussion groups have "proven to be effective networks, an insufficient number of farmers are, however, involved as members of these groups".

Overall, the importance of discussion groups is very positive and its impact seems effective within the context of Irish agricultural and particularly as it relates to on-farm practices. Boyle (2012: 3) further indicates this importance in that he suggests that discussion groups "could be considered as classic examples of 'nudge' measures in that they provide a relatively gentle encouragement to farmers to adopt technology through the medium of "peer to peer' learning". Their specific usefulness and impact on farm practices can be measured by the fact that over 10,000 farmers are involved in such groups and by the evidence from research showing that discussion group membership "has a positive impact on technology adoption and profit levels" (Hennessy, Heanue 2012: 41). However, with funding being withdrawn or coming to an end (for example funding for the Dairy Efficiency Programme (DEP) is now finished), it will be interesting to see if discussion groups created when the DEP began will continue or disband. That is, if the efforts by the extension advisory and the investment in terms of funding will have a long-term sustaina- 
ble effect, or, on their withdrawal, if the developments and networks accrued will fade away.

\subsection{The Options programmes}

In contrast to the farmer-advisor relationship as outlined in the discussion groups, the second example is reflective of an attempt to consider a more inclusive, participatory form of extension delivery as introduced by Teagasc through its Options for Farm Families Programme in 2001. This opportunity arose in 2000, when the 20002006 National Development Plan looked to Teagasc to "encourage and support farm families who were having viability problems, through their new Rural Viability Advisory Programme" (National Development Plan, p. 113). In response, Teagasc devised and applied a completely new advisory programme called the Opportunities for Farm Families Programme in 2001. Its fundamental objective was to help farm families generate additional household income and to improve their quality of life. The programme represented a change in both the content and provision of advisory services to farm families in Ireland, and in many respects followed Swanson's (2008) notion that the principal mission of a public extension system should be human resource development that equips medium and small-scale farmers to solve their own problems and respond to new opportunities (Farrell 2009). It was a family-focused multifunctional programme that ideally required a participatory approach to ensure successful delivery.

The Opportunities Programme was a free programme for farm families with less than 100 income units (i.e. 180,000 litres of milk quota, 100 beef cattle, 600 sheep, 100 hectares cereals or equivalent) and involved the initial stage of viability appraisal leading to the identification of a 'Way Forward Guide', with a second stage involving the analysis of future options for the farm family and the development of the 'Way Forward Action Plan'. Stages were delivered through facilitated group sessions with referrals to other agencies where necessary. The majority of participants taking part in the Opportunities Programme considered it to be either "some or a significant benefit to them", and the greater part of advisers felt that the programme "could help the farm family take a realistic look at their current situation" and assist in improving their quality of life through better work organisation (Bogue 2004: 3). There was, however, reluctance among some advisers to become involved in the programme and to adopt a change in extension approach partly due to workload, time constraints in dealing with families; few future options available, recruitment, and their own preference to disseminate technical agricultural information (Bogue 2004, 2005; Farrell 2009; Farrell, McDonagh 2012).

The difficulties surrounding the Opportunities Programme were considered and acted upon by Teagasc, and in 2004 they re-launched the Opportunities Programme as the Planning Post-Fischler Programme (PPFP). The launch coincided with Ireland's decision to opt for full decoupling which introduced the new single farm payment, and in many respects was a time of great indecision and confusion in Irish agriculture. Although the programme content remained largely intact, new targets were established and changes within the operational structure of the programme resulted in the programme becoming available to a greater number of farm families, both Teagasc clients and non-Teagasc clients (Teagasc 2004). The aims of the PPFP were similar to the Opportunities Programme, with the programme assisting families in reviewing the changing needs of the farm family. Priority issues addressed included: farming systems in post-CAP reform; current and future household income; balancing of workload; succession; isolation; and EU and national regulations (Bogue 2005: 1). As with the Opportunities Programme, action research was carried out, and while this was considered a priority programme within the remit of the Teagasc advisory services, the low level of response from advisers was a significant concern. Equally, over $70 \%$ of participants believed that it did not explore options available outside the farm, and nearly $25 \%$ of farm families were unaware of their involvement in the programme although they had been registered as having participated (Bogue 2005). Whatever the reasons for this, it seems fair to suggest that the level impact of the programme was so low that it was easy for farm families to forget they were even involved. On a positive note, in relation to 
those who did participate, the programme was well received with over half considering the programme instrumental in helping them identify the best farming system for the future.

The underlying theory behind the PPFP is that the deliverers of this programme are not there to identify or allocate alternative on-farm/ off-farm options for the farming community, but to initiate debate and interest among the farm family and to facilitate by providing a route by which information can be obtained. This concept is very much in line with the 'participatory approach' to extension identified by Haug (1999) and Pretty and Chambers (2000). The advisers are facilitators of the information and are only present to challenge the farm family into seeking their own solution. They are not there to provide answers or immediate solutions, which is the principal aspect of participatory theory of extension. The farm family may well have expected immediate answers relating to future options from their adviser and in failing to obtain this information, disappointment in the programme resulted. In turn, advisers may have felt under pressure to provide all the answers to the farm family, which may have resulted in an aversion to programme delivery. According to Bogue (2004), there were many issues of concern, primarily the participation and delivery method, but among the most prominent were issues of commitment and interest among advisers. Other issues of concern should have been the planning process surrounding the first two programmes. In failing to plan adequately, management laid the groundwork for an extension programme that was encountering difficulties before it was even implemented at farm level. However, little or no consideration was given to planning errors, and by September 2005 a third advisory programme, called the Options for Farm Families Programme, was launched.

\subsubsection{The Options for Farm Families Programme}

Preceding the launch of the Options for Farm Families Programme, twelve one-day sessions with advisers and specialists were organised. Following discussions and recommendations, several changes and alterations were introduced and included in the Programme. One of the most fundamental modifications of the previous two programmes was the omitting of the open information and discussion stage. Although a high percentage of the advisers found this stage both interesting and valuable, several difficulties arose in facilitating the meetings. Co-ordinating farmer meetings required a strong degree of commitment among the advisers, and although many may have been committed, they may possibly have lacked the basic skills and 'drive' to perform such a task (Bogue 2005). The Programme involved one on-farm visit with unlimited phone and office visits to support the delivery of an Action Plan. A new 'direct marketing to farmers' strategy, which was already in place, was to be continued and amplified through national radio campaigns, ploughing championship, the Farmers Journal newspaper, and ground-level marketing, i.e. talking to farmers about Options at every conceivable opportunity (Farrell, McDonagh 2012).

A new Advisor Handbook was drawn up in conjunction with a clear planning template for the farm family, which acted as one form of in-service training for advisers and was complemented with additional training days. However, it is worth noting that recommendations provided by Bogue (2004) and (2005), which identified concerns surrounding advisers' belief and commitment to the programme, remained largely unaddressed. One of the most challenging aspects of the Options Programme lay within its main objective, "to stimulate and support farm families in building the capacity of the farm household to increase income and improve quality of life" (Farrell 2009). This somewhat vague and all-encompassing objective is an example of what creates difficulties for advisory personnel and can be confusing for programme participants (Cristóvão et al. 1998). The specific objectives of the new Programme were more clearly defined and thus more measurable in terms of achieved outputs. These included: the need to assist the farm family in examining their current situation; identify their future needs; examine all possible options both on-farm and off-farm; draw up an Action Plan for the future; identify critical advisory training and referral needs, and implement a plan of action (Teagasc 2005). A key intended feature of the programme was to achieve a high level of engagement between farm families and their adviser on a one-toone basis, resulting in the development of a plan 
that identified specific actions for that farm family in the immediate and longer term.

In opting for a participative, discussion-based approach involving the adviser and family members, the Options Programme targeted issues of central concern and explored potential options both on-farm and off-farm for the farm family. In Ireland, the traditional focus on the male as farmer and main decision-maker remains strong, particularly in terms of decisions related to farming activities such as labour allocation and production (O'Hara 1998). However, acknowledgement of the importance of other family members in the decision-making process can be regarded as one of the core elements to the successful delivery of the Options Programme. These "Significant Others" or "Trusted People" (Errington 1986) are seen as valuable opinion sources within the farming family unit and important players in making decisions about future options. However, as Jiggins et al. (1998) argue, agricultural extension services still do not attach great importance to reaching women farmers or women on the farm, and many policy makers and administrators still assume that men are the farmers and the woman of the household is just there in a supportive capacity. In theory, at least, Teagasc seemed to have recognised this in designing the Options Programme to include all family members, and as such presented an important break with past tradition.

In delivering the Options Programme the process was designed to be carried out by a local adviser through a very definite process of stage development. This involved an initial viability appraisal which allowed the farm family to identify their main household concerns and to explore possible future options both on-farm and off-farm, which were then documented in a Way Forward Action Plan. The plan outlined specific aims and objectives that could generate additional income and improve the quality of life of the family. In addition to assistance from the adviser, a referral system was available that put farm families in contact with other relevant agencies that could help realise the successful outcome of the Action Plan. In the final stage of the programme, the farm family implemented the specific actions documented in their Action Plan and within twelve months the Teagasc adviser carried out a follow-up visit to ascertain the success or failure of the Plan (Farrell et al. 2008).

In their evaluation of the Options programme, Farrell and McDonagh (2012) suggested, however, that the dominant top-down implementation of the programme led to considerable problems, such as inadequate programme delivery methods; a lack of programme awareness and participation; workload issues; target issues; confidence levels among staff, and inadequate and inappropriate training. In fact there were a range of weaknesses inherent in the programme ranging from "a continuing 'paternalistic' attitude towards providing advice to farmers, reservations about their ability to provide the range of advice needed, the apparent failure of the referral service, and concerns about additional workload" (Farrell, McDonagh 2012: 53). On a positive note, they suggested, however, that the Options Programme did begin a very important process of engaging in broader rural development and thereby allowing the concept of multifunctionality to become part of the remit of the advisory service in terms of future direction. Despite the obvious shortfalls identified by Farrell (2009) and Farrell et al. (2008), the Options programme has continued to survive, albeit in a reconstituted state. To this end the ability of Teagasc to react to the changes deemed necessary and their willingness to engage more broadly in rural development issues has seen the rollout of a series of national meetings that have brought together rural development specialists, extension advisers and farm families in charting a way forward that promotes rural sustainability. The selection of a limited number of advisers to engage in this process seems to have been beneficial in terms of increased enthusiasm and buy-in by these advisers in relation to what could be achieved. Further, while there have been no evaluations of this new working environment, anecdotal evidence would suggest that the feedback from those involved is very positive.

\section{Concluding comments}

The radical re-shaping of rural Europe by international policy developments and the threefold challenge of climate change, energy security and 
food security, places agricultural and rural development in a uniquely challenging position. The twin pursuits of competitiveness and sustainability, allied to forthcoming CAP reforms, suggest a future rural landscape that will encompass a multifunctional agricultural regime, diversification of rural economies and heightened concerns "in relation to the future economic, social and environmental sustainability of Europe's rural regions" (Downey 2006: 8). In the context of such fundamental change, the shaping of modern agricultural practices and rural activities will require more direction, foresight and advice than ever before. To this end the role of the extension advisory services is increasingly recognised as central. From the discussions thus far, it is clear that the extension advisory has undergone radical change with varying degrees of success in moving away from the traditional top-down paternalistic approach focused on improving farming practices specifically, to an approach that values participation of all key actors both on farm and in the wider rural arena. What is also apparent is that this is not an easy or uneventful process, and the implementation and managing of such change is a crucial part (Bogue, Phelan 2005). Extension professionals are increasingly forced to embrace a broadened mandate, with two agendas equally important: agricultural modernisation and rural development. To successfully support both agendas, the delivery methods and approaches of extension services have made radical changes over time. Participatory approaches, which focus on learning and empowerment, have increasingly gained in importance and significance (Anderson 2008; Pannell 2006). A participatory approach to extension encompasses a bottom-up, holistic approach that represents a dramatic move away from the technology-transfer model of the past towards a facilitative approach that considers the needs and wants of the community first and foremost. The adoption of this method to extension requires a creative approach to programme delivery and continuous efforts on the part of extension managers and advisers. However, the adoption of a participatory approach, according to Cristóvão et al. (1998), can lead to social and political conflicts as it touches the question of power, and in particular the advisors who may lose power and the farming community that gain it. This often leads to a resistance from advisory professionals to accept a shift to participatory approaches, and instead they hold steadfast to older 'paternalistic' methods of extension delivery. In the examples given, it is clear how the delivery approaches used can work, or equally can prevent progress. It is in finding the right blend of top-down and participatory engagement that will prove to be the greatest challenge in future striving toward farm viability and broader rural sustainability. What manner or form this takes will ultimately determine whether some rural areas thrive and flourish or whether they decline and become marginalised. On a broader European stage, the introduction of the European Innovation Partnership (EIP) may just be the type of initiative that may provide the springboard for the former rather than the latter.

The aim of the European Innovation Partnership is "to foster a competitive and sustainable agriculture and forestry that 'achieves more from less' input and works in harmony with the environment" (Van Oost 2012: 11). The significance of this development would seem to lie in the recognition of the multi-actor make-up of rural areas, and not only of the importance of farmers as key innovators, but that innovations can come from a myriad places, individuals or groups, and the facilitation of common ground is paramount. The EIP subsequently sets its agenda as one of building "bridges between research and technology and stakeholders (farmers, businesses and advisory services), ... a (type of) 'interactive innovation model' which focuses on forming partnerships using bottom-up approaches" (Van Oost 2012: 11). This linking of support from rural development policy and research and innovation policy (Food harvest 2020) in supporting the development of Operational Groups (OGs) suggests a more broadly engaged approach to rural challenges and opportunities. In the years ahead it will be interesting to observe how the EIP functions and whether it can live up to its desire to bring together the multi-actor make-up of rural areas.

\section{References}

Alsos G.A., Carter S., 2006. Multiple business ownership in the Norwegian farm sector: resource transfer and performance consequences. Journal of Rural Studies 22: 313-322. 
Anderson J.R., 2008. Agricultural Advisory Services. Background Paper for World Development Report 2008. Agriculture for Development Department, the World Bank, Washington, DC.

Barbieri C., Valdivia C., 2010. Recreation and agroforestry: Examining new dimensions of multifunctionality in family farms. Journal of Rural Studies 26(4): 465-473.

Black A.W., 2000. Extension theory and practice: A review. Australian Journal of Experimental Agriculture 40(4): 493502.

Bogue P., 2004. An assessment of the Opportunities for Farm Families Programme. Rural Development Conference Proceedings 2004. Rural Economy Research Centre, Teagasc, Ireland.

Bogue P., Phelan J., 2005. Advisory services in transition: The challenge of change. Paper presented at the AIAEE, $22^{\text {nd }}$ Annual Conference Proceedings, Clearwater Beach, Florida, USA.

Boyle G., 2012. Enhancing Irish agricultural productivity through technology adoption: a critique of the Irish agricultural, knowledge and innovation system (AKIS). In: Heanue K., Mackan-Walsh A., Maher P. (eds), Teagasc best practice in extension services. Conference Proceedings, Nov. $1^{\text {st }}$ 2012, Teagasc: 1-6.

Breen J., Hennessy T., Thorne F., 2005. Decoupled payments and the decision to produce. Rural Economy Research Centre, Teagasc, Working Paper Series, Working Paper 05-WPRE-02.

Burton R., Wilson G.A., 2006. Injecting social psychology theory into conceptualisation of agricultural agency: Towards a post-productivist farmer self identity? Journal of Rural Studies 22(1): 95-115.

Carey D., 2004. The Teagasc extension advisory training servicethe Irish public/ private extension model. Paper presented at Association for International Agricultural and Extension Education Conference, Dublin.

Central Statistics Office (CSO), 2004. Farm structure survey. Government Publications, Dublin, Ireland.

Commins P., 1995. The European Community and Irish rural economy. In: Clancy P., Drudy S., Lynch K., O’Dowd L. (eds), Irish society: Sociological perspectives. Institute of Public Administration with Sociological Association, Dublin.

Connolly L., Kinsella A., Quinlan G., Moran B., 2003. The National Farm Survey 2002. Teagasc: Rural Economy Research Centre, Athenry, Galway.

Connolly L., Kinsella A., Quinlan G., Moran B., 2005. The National Farm Survey 2004. Teagasc: Rural Economy Research Centre, Athenry, Galway.

Cristóvão A., Koehnen T., Portela J., 1998. Developing and delivering extension programmes. In: Swanson B.E. Bentz R.P., Sofranko A.J. (eds), Improving agricultural extension: A reference manual. UN Food and Agricultural Organisation, Rome: 57-65.

Crowley E., 2003. The evolution of the Common Agricultural Policy and social differentiation in rural Ireland. Economic and Social Review 34(1): 65-85.

Downey L., 2006. EU agri-food industries, rural economies by 2025. School of Agriculture, Food Science \& Veterinary Medicine, University College Dublin.

Errington A., 1986. The delegation of decision on the farm. Agricultural Systems 19: 299-317.

Farrell M., 2009. Embracing multifunctional agriculture in the Republic of Ireland: Towards a new extension ethic. Unpub- lished PhD Thesis, National University of Ireland, Galway.

Farrell M., McDonagh J., 2012 The importance of evaluation - The case of the 'Options for Farm Families Programme' in Ireland. Journal of Agricultural Education and Extension 18(2): 105-120.

Farrell M., McDonagh J., Mahon M., 2008. The Options for Farm Families: Rhetoric and reality of change. Journal of International Agricultural and Extension Education 15(3): 39-59.

Feder G., Willett A., Zijp W., 2001. Agricultural extension: Generic challenges and the ingredients for solutions. In: Wolf S., Zilberman D. (eds), Knowledge generation and technical change: Institutional innovation in agriculture. Kluwer Publishers, Boston: 313-56.

Frawley J., Keeney M., 1999. The impact of direct payments on farm income distribution. End of Project Report No. 4656, Teagasc, Dublin.

Fulton A., Fulton D., Tabart T., Ball P., Champion S., Weatherley J., Heinjus D., 2003. Agricultural extension, learning and change. Rural Industries Research Development Corporation, Publication No 03/032, RIRDC Project No RDP-1A, Canberra, Australia.

Garforth C., 2004. Introduction. In: Rivera W., Gary A. (eds), Demand driven approaches to agricultural extension. Agricultural and Rural Development, Discussion Paper 10, Extension Reform for Rural Development. The World Bank.

Garforth C., Angell B., Archer J., Green K., 2003. Improving farmers' access to advice on land management: Lessons from case studies in developed countries. Agricultural Research and Extension Network, Network Paper No. 125.

Haug R., 1999. Some leading issues in international agricultural extension, a literature review. Journal of Agricultural Education and Extension 5(4): 263-274.

Grande J., 2011. New venture creation in the farm sector Critical resources and capabilities. Journal of Rural Studies 27: 220-233.

Heanue K., Mackan-Walsh A., Maher P. (eds), 2012. Teagasc best practice in extension services. Conference Proceedings, Nov. $1^{\text {st }}$ 2012, Teagasc.

Hennessy T., Heanue K., 2012. Quantifying the effect of Discussion Group membership on technology adoption and farm profit on dairy farms. Journal of Agricultural Education and Extension 18(1): 41-54.

Food harvest 2020, 2010. Department of Agriculture, Fisheries and Food, Dublin.

Jiggins J., Samanta R.K., Olawoye J.E., 1998. Improving women farmers' access to extension services. Improving agricultural extension: A reference manual. UN Food and Agricultural Organisation, Rome: 73-82.

Jones G.E., Garforth C., 1997. The history, development, and future of agricultural extension. Improving agricultural extension: A reference manual (3rd ed.). UN Food and Agricultural Organisation, Rome.

Lafferty S., Commins P., Walsh, J., 1999. Irish agriculture in transition: A census atlas of agriculture in the Republic of Ireland. Teagasc, Dublin.

Leeuwis C., 1989. Marginalization misunderstood; different patterns of farm development in the west of Ireland. Wageningse Sociologische Studies 26, Wageningen Agricultural University.

Leeuwis C., van den Ban A.W., 2004. Communication for rural innovation: Rethinking agricultural extension. Blackwell Publishing Ltd., Oxford (3rd ed.). 
Lenihan M., Ruane D.J., Phelan J.F., 2002. The role of off-farm business development in creating a sustainable rural environment. Tearmann (2): 85-95.

Lopez-i-Gelats F., Milan M.J., Bartolome J., 2011. Is farming enough in mountain areas? Farm diversification in the Pyrenees. Land Use Policy 28: 783-791.

Lucey C., 2004. Going forward with the CAP and WTO. Agriculture thriving in transition. The Farmers Journal 12/4/2004, Ireland.

Marsden T., Sonnino R., 2008. Rural development and the regional state: Denying multifunctional agriculture in the UK. Journal of Rural Studies 24(4): 422-431.

McDonagh J., 2013. Rural geography I: Changing expectations and contradictions in the rural. Progress in Human Geography. Online, 18 January, DOI: 10.1177/0309132512474404

Moreno-Pérez O.M., Arnalte-Alegre E., Ortiz-Miranda D., 2011. Breaking down the growth of family farms: A case study of an intensive Mediterranean agriculture. Agricultural Systems 104: 500-511.

Morrison S., 2012. Supporting the development needs of farmers. In: Heanue K., Mackan-Walsh A., Maher P. (eds), Teagasc best practice in extension services. Conference Proceedings, Nov. $1^{\text {st }} 2012$, Teagasc: $12-13$.

Murray P., 2000. Evaluating participatory extension programs: Challenges and problems. Australian Journal of Experimental Agriculture 40(4): 519-526.

O'Hara P., 1998. Partners in production? Women, farm and family in Ireland. Berghahn Books, New York.

Pannell D., 2006. Adoption of conservation practices by rural landlords: Implications from research and extension. Pannell Discussions Paper No. 86, University of Western Australia.

Phelan J., 1998. Trends in Irish agriculture: Implications for extension and rural development. Journal of International Agricultural and Extension Education 5(3): 55-59.

Potter C., Burney J., 2002. Agricultural multifunctionality in the WTO: Legitimate non-trade concern or disguised protectionism? Journal of Rural Studies 18(1): 35-47.

Pretty J.N., 1995. Participatory learning for sustainable agriculture. World Development 23(8): 1247-1263.

Pretty J.N., Chambers R., 1994. Towards a learning paradigm: New professionalism and institutions for agriculture. In: Scoones I., Thompson J. (eds), Beyond farmer first: Rural people's knowledge, agricultural research and extension practice. Intermediate Technology Publications, London: 182-202.

Pretty J.N., Chambers R., 2000. Toward a learning paradigm: New professionalism and institutions for agriculture. In: Harris J.H. (ed.), Rethinking sustainability. Michigan University Press: $173-189$.

Qamar M.K., 2001. Global trends in reforming extension services: Implications for rural development education and training. Paper presented at International Workshop on Technical Training for Rural Development: Looking to the 21st Century, Baoding, China.

Rivera W., 1996. Agricultural extension in transition worldwide: Structural, financial and managerial strategies for improving agricultural extension. Public Administration and Development 16(2): 151-161.

Rivera W.M., 2008. Pathways and tensions in the family of reform. Journal of Agricultural Education and Extension 14(2): 101-109.
Rivera W.M., Qamar M.K., 2003. Agricultural extension, rural development and food security challenge. UN Food and Agricultural Organisation, Rome.

Rivera W.M., Qamar M.K., Crowder L.V., 2001. Agricultural and rural extension worldwide: Options for institutional reform in developing countries. UN Food and Agricultural Organisation, Rome.

Share P., Tovey H., Corcoran M., 2007. A sociology of Ireland. Gill and Macmillan, Dublin.

Shortall S., 2004. Social or economic goals, civic inclusion or exclusion? An analysis of rural development theory and practice. Sociologia Ruralis 44(1): 109-123.

Somers N., 1998. Learning about sustainable agriculture: The case of Dutch arable farmers. In: Röling N.J., Wagemakers M. (eds), Facilitating sustainable agriculture. Cambridge University Press, Cambridge: 125-133.

Swanson, B.E., 2008. Global review of good agricultural extension and advisory practices. UN Food and Agriculture Organization, Rome.

Swanson B.E., Samy M., 2002. Developing an extension partnership among public private and nongovernmental organisations. Journal of International Agriculture and Extension Education 9(1): 5-10.

Teagasc Agriculture and Food Development Authority, 1995. Research / Advisory / Training Services, 1995-1999. Teagasc, Dublin.

Teagasc Agriculture and Food Development Authority, 1998. Teagasc 2000 - Statement of Strategy. Available at: http:/ / www.teagasc.ie/ aboutus/ strategy/ strategy_10.asp, Dublin.

Teagasc Agriculture and Food Development Authority, 2004. Planning post Fischler programme - Guidelines. Teagasc Staff Information Document, Teagasc, Dublin.

Teagasc Agriculture and Food Development Authority, 2005. Options for Farm Families Programme. Teagasc, Dublin.

Thrup L.A., Altieri M., 1998. Knowledge generation and technical change. In: Wolf S., Zilberman E. (eds), Knowledge generation and technical change: Institutional innovation in agriculture. Kluwer, Boston: 267-290.

van den Ban A.W., Hawkins H.S., 1996. Agricultural extension. Blackwell Science, Oxford (2nd ed.).

van Oost I., 2012. The European Innovation Partnership (EIP) 'Agricultural Productivity and Sustainability' and the proposals for the Farm Advisory System (FAS). In: Heanue K., Mackan-Walsh A., Maher P. (eds), Teagasc best practice in extension service. Conference Proceedings, Nov. $1^{\text {st }}$ 2012, Teagasc: $11-12$.

Watson C., 2012. The role of professional advisers. In: Heanue K., Mackan-Walsh A., Maher P. (eds), Teagasc best practice in extension services. Conference Proceedings, Nov. $1^{\text {st }}$ 2012, Teagasc: 14-15.

Wilson G.A., 2001. From productivism to post-productivism ... and back again? Exploring the (un)changed natural and mental landscapes of European agriculture. Transactions of the Institute of British Geographers 26(1): 77-102.

Wilson G., Rigg J., 2003. 'Post-productivist' agricultural regimes and the South: Discordant concepts? Progress in Human Geography 27(6): 681-707.

World Bank, 2002. Extension and rural development: A convergence of views on institutional approaches? International Workshop, Nov. 12-14. The World Bank, Washington, DC. 